\title{
PENGARUH KOMUNIKASI DAN LINGKUNGAN KERJA TERHADAPKINERJA KARYAWAN PADA PT. JASA MARGA (PERSERO) TBKCABANG BELMERA MEDAN
}

\author{
${ }^{1}$ Julita, ${ }^{2}$ Nel arianty \\ Fakultas Ekonomi dan Bisnis Universitas Muhammadiyah Sumatera Utara \\ e-mail:ljulita@umsu.ac.id
}

\begin{abstract}
ABSTRAK
Penelitianini bertujuan untuk mengetahui pengaruh komunikasi terhdap kinerja karyawan,pengaruh lingkungan kerja terhadapkinerja karyawan, serta pengaruhkomunikasi dan lingkungan kerja terhadap kinerja karyawan pada PT. Jasa Marga (Persero) Tbk Cabang Belmera Medan.Analisis yang digunakanmeliputi analisis regresi linier berganda, dan (uji $\mathrm{T}$, dan uji $\mathrm{F}$, koefisien determinasi) digunakan sebagai metode analisisnya. Berdasarkan hasil analisis ditemukan bahwa variabel komunikaasi dan lingkungan kerja secara parsial dan secara simultan berpengaruh signifikan terhadap kinerja karyawan pada PT. Jasa Marga (Persero) Tbk Cabang Belmera Medan.
\end{abstract}

Kata Kunci: Komunikasi, Lingkungan Kerja, Kinerja Karyawan

\begin{abstract}
This study aimed to determine the effect of communication on the performance of the employee, the work environment influence on employee performance, as well as communication and working environment influences the performance of employees at PT. Jasa Marga (Persero) Tbk CabangBelmera Medan. The analysis includes multiple linear regression analysis, and ( $\mathrm{T}$ test and $\mathrm{F}$ test, the coefficient of determination) is used as the method of analysis. Based on the analysis found that variables communication and partially working environment and simultaneously significant effect on the performance of employees at PT. Jasa Marga (Persero) Tbk CabangBelmera Medan.

Keywords :Communication, Environment Work, Employee Performance
\end{abstract}

\section{PENDAHULUAN}

Dalam organisasi sumberdaya manusia merupakan pendukung utama untuk mencapai tujuan yang telah ditetapkan. Sumber daya manusia yang berkualitas akan turut memajukan organisasi sebagai wadah untuk meningkatkan kinerja yang baik. Sedarmayanti (2007, hal. 259) menyatakan pentingnya kinerja bagi keberlangsungan sebuah organisasi adalah untuk melakukan, menjalankan, melaksanakan, serta menyempurnakan tanggung jawab.

Kinerja karyawan dipengaruhi beberapa faktor di antarannya adalah kemampuan, motivasi, faktor pengetahuan, lingkungan kerja, posisi strategis, proses kemanusiaan, struktur, faktor kepribadian, faktor kepuasan, gaya kepemimpinan, faktor tim kerja, dan faktor teknologi dan fasilitas. 
Komunikasi merupakan suatu proses dari penyaluran informasi, baik dari dalam maupun dari luar organisasi secar timbal balik, komunikasi yang efektif adalah merupakan alternatif yang paling diinginkan guna memenuhi secara tepat dan efisien penyampaian pesan, intruksi-intruksi dan umpan baliknya dari para bawahan. Sekaligus mengkoreksi apakah pesan yang disampaikan dapat dimengerti dan diterima dengan baik oleh para bawahannya. Keseluruhan proses intruksi itu akansangat bermanfaat bagi pencapaian tujuan organisasi sesuai dengan rencana yang telah ditetapkan.

Lingkungan kerja adalah segalah sesuatu yang ada disekitar para pekerja yang dapat mempengaruhi dirinya dalam menjalankan tugastugas yang di jalankan. Kualitas lingkungan kerja dalam arti kondisi ruang kerja yang nyaman dan sehat, sangat mempengaruhi kesegaran dan semangat kerja karyawan. Dimana setiap organisasi harus mempunyai kesempatan yang cukup untuk mengendalikan lingkungan kerja dan harus menyadari perlunya menyediakan lingkungan kerja yang sesuai untuk para karyawan dalam melaksanakan tugas-tugas mereka. Sebab, apabila lingkungan kerja memadai maka kinerja karyawan akan menjadi lebih baik. Karena lingkungan kerja menyangkut tempat kerja.

Maka dari itu organisasi harus menyediakan lingkungan kerja yang memadai seperti lingkungan fisik (tata ruang kantor yang nyaman, lingkungan yang bersih, pertukaran udarah yang baik, warna, penerang yang cukup maupun musik yang merdu), serta lingkungan non fisik (suasana kerja karyawan, kesejahteraan karyawan, hubungan antar sesama karyawan, hubungan anatarkaaryawan dengan pimpinan, serta tempat ibadah). Lingkungan kerja yang baik dapat mendukung pelaksanaan kerja sehingga karyawan memiliki semangat bekerja dan meningkatkan kinerja karyawan. Manajemen Sumber Daya Manusia sangat penting bagi sebuah perusahaan dalam mengelola, mengatur dan memanfaatkan karyawan atau pegawai. Sehingga dapat berfungsi secara produktif untuk tercapainya tujuan perusahaan tersebut. Tenaga kerja atau karyawan merupakan Sumber Daya Manusia yang sangat penting dalam suatu perusahaan, karena tanpa karyawan perusahaan tidak dapat berjalan dengan baik. Karyawan adalah sebagai modal utama bagi setiap perusahaan. Modal yang dimiliki oleh setiap karyawan perlu dikelola agar tetap produktif dalam pekerjaannya. Akan tetapi dalam pengelolaannya bukanlah hal yang mudah, karena karyawan mempunyai fikiran, status, serta latar belakang heterogen. Oleh sebab itu pimpinan perusahaan harus bisa mendorong mereka agar tetap produktif dalam mengerjakan tugasnya masing-masing, dengan cara terus menerus meningkatkan prestasi kerja para karyawannya. Sehingga perusahaan dapat mempertahankan loyalitas karyawan guna untuk mencapai tujuan perusahaan.

Berdasarkan informasi yang penulis dapatkan dari riset pendahuluan yang dilaksanakan padaPT. Jasa Mrga (Persero) Tbk Cabang Belmera Medan masalahmasalah yang terlihat diantaranya 
kinerja karyawan yang masih belum optimal dalam melaksanakan pekerjaan yang menjadi tanggung jawabnya, kurangnya komunikasi yang baik disetiap bidang, yangr mengakibatkan kinerja karyawan belum tercapai secara optimal. Lingkungan kerja di perusahaan masih terdapat kekurangan diantaranya peralatan-peralatan yang masih rusak dan belum diperbaiki, pendingin ruang (AC) serta penataan ruang kerja yang kurang baik hal ini disebabkan ruang kerja menjadi sempit dan kurang nyaman sehingga peningkatan kinerja yang masih belum maksimal.

\section{KAJIAN TEORITIS}

\section{A. Pengertian Kinerja}

Kinerja merupakan suatu yang sangat penting dalam upaya perusahaan untuk mencapai tujuannya.Kinerja merupakan prilaku nyata yang ditampilkan setiap orang sebagai prestasi kerja yang dihasilkan karyawan sesuai perannya dalam perusahaan.

Menurut Prawirosentono dalam EdySutrisno (2011, hal. 170)Kinerja adalah hasil kerja yang dapat dicapai oleh seseorang atau sekelompok orang dalam suatu organisasi, sesuai dengan wewenang dan tanggung jawab masing-masing, dalam rangka upaya mencapai tujuan organisasi bersangkutan secara legal, tidak melanggar hukum, dan sesuai dengan moral dan etika.

\section{B. Manfaat Penilaian Kinerja}

Menurut UsainiHusman (2011, hal. 490) manfaat penilaian kinerja dapat dirinci sebagai berikut :

1) Meningkatnyaobjektivitas penilaian kinerja karyawan
2) Meningkatnya keefektifan penilaian kinerja karyawan

3) Meningkatnya kinerja karyawan

4) Mendapatkan bahan-bahan pertimbangan yang objektif dalam pembinaan karyawan tersebut baik berdasarkan sistem karier maupun prestasi

\section{Faktor-Faktor Mempengaruhi Kinerja}

Kinerja yang dicapai karyawan merupakan suatu hal yang sangat penting dalam menjamin kelangsungan hidup suatu organisasi di masa yang akan datang. Dalam mencapai kinerja yang tinggi ada beberapa faktor yang mempengaruhi menjadi acuan apakah kinerja karyawan tinggi atau rendah.

Menurut Mangkunegara (2013, hal. 67) menyebutkan faktor yang mempengaruhi pencapaian kinerja adalah faktor kemampuan (ability) dan faktor motivasi (motivation).

1) Faktor kemampuan

Secara psikologis, kemampuan (ability) karyawan terdiri dari kemampuan potensi (IQ) dan kemampuan reality (knowladge + skill). Oleh karena itu, karyawan perlu ditempatkan pada pekerjaan yang sesuai dengan keahliannya.

2) Faktor motivasi

Motivasi terbentuk dari sikap (attitude) seorang karyawan dalam menghadapi situasi (situation) kerja. Motivasi merupakan kondisi yang menggerakan diri karyawan yang terarah untuk mencapai tujuan organisasi. Sikap mental merupakan kondisi mental 
yang mendorong diri karyawan untuk berusaha mencapai prestasi kerja secara maksimal. Sikap mental seorang karyawan harus sikap mental yang siap secara psikofisik (siap secara mental, fisik, dan situasi). Artinya, seorang karyawan harus siap mental, mampu secara fisik, memahami tujuan utama dan target kerja yang akan dicapai, mampu memanfaatkan, dan menciptakan situasi kerja.

\section{Indikator kinerja}

Indikator kinerja (performance indicator) sering disamakan dengan ukuran kinerja(performance measure), namun sebenarnya meskipun keduanya merupakan sama-sama dalam kriteri pengukuran kinerja, tetapi terdapat perbedaan arti dan maknanya. Pada indikator kinerja (performance indicator) mengacu pada penilaian kinerja secara tidak langsung, yaitu hal-hal yang bersifat hanya merupakan indikasi kinerja saja, sehingga bentuknya cenderung kualitatif atau tidak dapat dihitung. Sedangkan ukuran kinerja (performance measure) adalah kriteria yang mengacu pada penilaian kinerja secara tidak langsung, sehhingga lebih bersifat kuantitatif atau dapat dihitung.

Menurut Mangkunegara (2013, hal.75) "menyebutkan bahwa indikator kinerja terdiri dari kualitas kerja, kuantitas kerja, keandalan kerja,dan sikap kerja."

Berdasarkan indikator kinerja yang dikemukakan diatas dapat dijelaskan sebagai berikut :

1) Kualitas kerja
Kualitas kerja dapat dilihat dari ketepatan kerja, ketelitian, lketerampilan,dan kebersihan dari kerja seseorang.

2) Kuantitas kerja

Disebut juga dengan output, perlu diperhatikan juga bukan hanya output rutin, tetapi juga seberapa cepat bisa menyelesaikan kerja "extra"

3) Keandalan kerja Keandalan kerja terdiri dari mengikuti intruksi, inisiatif, hati-hatian, kerajinan.

4) Sikap kerja

Sikap kerja terdiri dari sikap terhadaperusahaan,karyawan

lain dan pekerjaan serta kerjasama.

\section{E. Pengertian Komunikasi}

Komunikasi adalah proses pemindahan suatu informasi, ide, pengertian dari seseorang kepada orang lain dengan harapan orang lain tersebut dapat menginterprestasikannya sesuai dengan tujuan yang dimaksud.

Komunikasi menurut Husaini Usman (2011, hal. 420) "komunikasi adalah yaitu proses penyampaian atau penerimaan pesan dari satu orang kepada orang lain, baik langsunng maupun tidak langsung, secara tertulis,lisan maupun bahasa nonverbal."

\section{F. Tujuan dan Manfaat Komunikasi \\ Menurut HusainiHusman} (2011, hal. 420) dapat dilihat sebagai berikut :

1) Sebagai sarana untuk meningkatkan kemampuan 
manajerial dan hubungan sosial.

2) Menyampaikan dan atau menerima informasi.

3) Menyampaikan dan menjawab pertanyaan.

4) Mengubah perilaku (pola pikir, perasaan, dan tindakan) melalui perencanaan, pengorganisasian, pengarahan, dan pengawasan.

5) Mengubah keadaan sosial.

6) Dua hal yang dapat mengubah perilaku dan keadaan sosial adalah komunikasi dan pengambilan keputusan.

\section{G. Jenis-jenis Komunikasi}

Ada beberapa jenis komunikasi yang dapat digunakan dalam suatu organisasi, menurut Kadarman, JusufUdaya (2001, hal. 151) menyatakan komunikasi dapat digolongkan dalam berbagai jenis seperti, komunikasi ke bawah, ke atas, dan kesamping secara menyilang. EdySutrisno (2011, hal. 45) menyatakan komunikasi dapat komunikasi dapat digolongkan dalam berbagai jenis seperti, komunikasi verbal dan nonverbal, komunikasi satu arah dan dua arah.

Berdasarkan pendapat diatas dapat disimpulkan jenis-jenis komunikasi yaitu komunikasi ke bawah, ke atas, dan kesamping secara menyilang, komunikasi verbal dan nonverbal, komunikasi satu arah dan dua arah.

\section{H. Indikator Komunikasi}

komunikasi merupakan proses pemindahan suatu informasi, ide, pengertian dari seseorang kepada orang lain dengan harapan orang laintersebut dapat menginterprestasikannya sesuai tujuan yang dimaksud.

Menurut Miftahthoha (2014, hal. 191), "menyatakan indikator komunikasi antar pribadi bisa efektif adalah, Keterbukaan, Empati, Dukungan, Kepositifan, Kesamaan."

Berdasarkan indikator komunikasi yang dikemukakan diatas dapat dijelaskan sebagai berikut :

1) Keterbukaan

Untuk menunjukan kualitas keterbukaan dari komunikasi antar pribadi paling sedikit ada dua aspek, yakni : aspek keinginan untuk terbuka bagi setiap orang yang berinteraksi dengan orang lain.Dengan keinginan untuk terbuka ini dimaksudkan agar diri masingmasing tidak tertutup didalam menerima informasi dan berkeinginan untuk menyampaikan informasi dari dirinya bahkan juga informasi mengenai dirinya kalau dipandang relevan dalam rangka pembicaraan antar pribadi dengan lawan bicaranya. Aaspek lainnya ialah keinginan untuk menanggapi secara jujur semua stimuli yang datang kepadanya.

2) Empati

Dengan empati dimaksudkan untuk merasakan sebagai mana yang dirasakan oleh orang lain suatu perasaan bersama perasaan orang lain yakni, mencoba merasakan dalam cara yang sama dengan perasaan orang lain. Dan yang paling penting ialah kita 
tidak bakal memberikan penilaian pada perilaku atau sikap mereka sebagai perilaku atau sikap yang salah atau benar.

3) Dukungan

Dengan dukungan ini akanakan tercapai komunikasi antar peribadi yang efektif. dukungan adakalanya terucapkan dan adakalanya tidak terucapkan. Dukungan yang tidak terucapkan tidaklah mempunyai nilai yang negatif, melainkan dapat merupakan aspek positif dari komunikasi. Sedangkan dalam keterbukaan dan empati komunikasi antarpribadi tidak bisa hidup dalam suasana yang penuh ancaman.

4) Kepositifan

Komunikasi akan berhasil jika terdapat perhatian yang positif terhadap diri seseorang. Komunikasi akan terpelihara baik jika suatu perasaan positif terhadap orang lain itu dikomunikasikan. Suatu perasaan positif dalam suatu komunikasi umum, amat bermanfaat untuk mengefektifkan kerja sama.

5) Kesamaan

Komunikasi bisa efektif jika orang-orang yang berkomunikasi itu dalam suasana kesamaan, bukan berarti bahwa orang-orang yang tidak mempunyai kesamaan tidak bisa berkomunikasi.

\section{Pengertian Lingkungan Kinerja}

Lingkungan kerja merupakan sesuatu yang ada pada sekitar perusahaan yang dapat mempengaruhi cara kerja dan kinerja dari para karyawan dan tempat kerja. Untuk lebih jelasnya lagi pengertian lingkungan kinerja akan dikemukakan oleh beberapa para ahli, yaitu :

Menurut Suyanto (2013, hal. 43) "Lingkungan kerja adalah sesuatu yang ada disekitar para pekerja dan yang dapat mempengaruhi dirinya dalam menjalankan tugas-tugas yang diberikan, misalnya kebersihan, musik, penerangan dan lainlain."Sedangkan menurut Sadarmayati (2009, hal. 21) "lingkungan kerja dikatakan baik atau sesuai apa bila manusia dapat melaksanakan kegiatannya secara optimal, sehat, aman dan nyaman."

\section{J. Indikator Lingkungan Kinerja}

Pada dasarnya banyak indikator yang digunakan untuk mengukur bagaimana lingkungan kerja yang baik. Menurut Sadarmayanti (2009, hal..28), "indikator lingkungan kerja adalah, Penerangan/cahaya ditempat kerja, Temperatur ditempat kerja, Kelembaban ditempat kerja, Sirkulasi udara ditempat kerja, Kebisingan ditempat kerja, Getaran mekanis ditempat kerja, Bau-bauan ditempat kerja, Tata ruang ditempat kerja, Dekorasi ditempat kerja, Musik ditempat kerja."

\section{METODOLOGI} PENELITIAN

\section{A. Tempat Penelitian}

Tempat penelitian ini dilakukan pada PT. Jasa Marga (Persero) Tbk Cabang Belmera Medan, di jln. Simpang Tanjung 
No. 1A, Medan 20241- Indonesia, T. (+62 61) 661 1701, 661 2920, F (62 61) 6611055.

\section{B. Waktu Penelitian}

Adapun waktu bagi penulis melakukan penelituan ini direncanakan pada bulan November 2015 sampai Maret 2016 dengan perincian sebagai berikut :

\section{Populasi penelitian}

Populasi adalah jumlah seluruh obyek yang karakteristiknya hendak diduga. Sugiyono (2012, hal. 115) bahwa "populasi merupakan wilayah yang generalisasi yang terdiri atas objek/subjek yang mempunyai kualitas dan karakteristik tertentu yang ditetapkan oleh peneliti untuk dipelajari dan kemudian ditarik kesimpulannya."

Populasi dari penelitian ini yaitu karyawan pada PT. Jasa Marga (Persero) Tbk Cabang Belmera Medan yang berjumlah 200 orang .

\section{Sampel}

Untuk penentuan jumlah/ukuran sampel dalam penelitian ini dengan teknik penarikan sampel yang digunakan yaitu Probability Sampling adalah teknik pengambilan sampel yang memberikan peluang yang sama bagi setiap unsur (anggota) populasi untuk dipilih menjadi anggota sampel.
E. Teknik Pengumpulan Data
1. Wawancara (interview)
2. Studi Dokumentasi
3. Angket (Kuesioner)

\section{HASIL PENELITIAN}

\section{A. Regresi Linier Berganda}

Analisis regresi digunakan untuk mengetahui pengaruh dari variabel bebas terhadap variabel terikat. Persamaan regresi dalam penelitian ini adalah sebagai berikut.

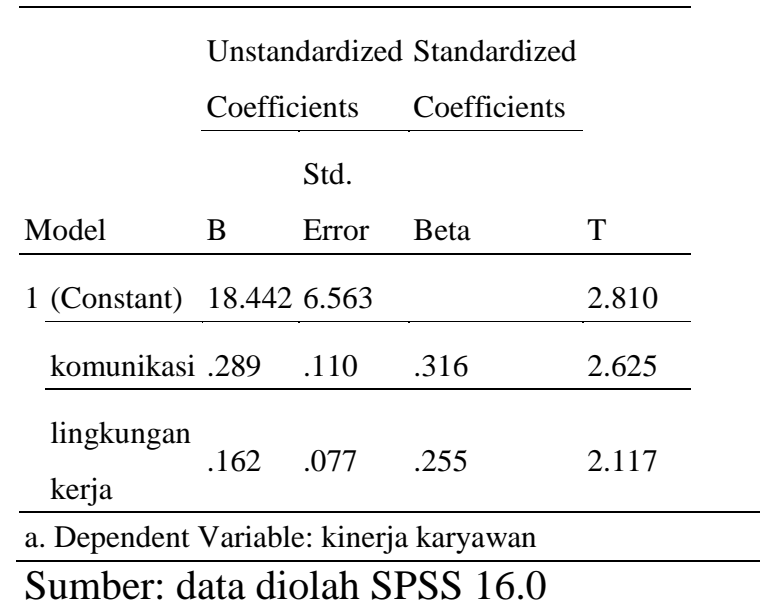

Dari tabel diatas, maka model persamaan regresinya adalah:

$$
\begin{array}{ll}
\mathrm{a} & =18.442 \\
\mathrm{~b}_{1} \mathrm{X}_{1} & =0,289 \\
\mathrm{~b}_{2} \mathrm{X}_{2} & =0,162 \\
\mathrm{Y} & =\mathrm{a}+\mathrm{b}_{1} \mathrm{X}_{1}+\mathrm{b}_{2} \mathrm{X}_{2}+\mathrm{e} \\
\mathrm{Y} & =(18.442)+0,289+ \\
& 0,162
\end{array}
$$

Berdasarkan persamaan regresi berganda tersebut dianalisis pengaruh dari masing - masing variabel independent terhadap variabel dependent(kinerja karyawan). Maka komunikasi berpengaruh sebesar 0,289 dan lingkungan kerja berpengaruh sebesar 0,162 .

\section{B. Uji T (parsial)}

Uji T (uji parsial) dilakukan untuk melihat secara individual pengaruh secara positif dan signifikan dari variabel bebas (independent) terhadap variabel terikat (Y). Uji t dilakukan dengan menggunakan tabel coefficient. 


\begin{tabular}{|c|c|c|c|c|}
\hline Coefficientsa & & & & \\
\hline \multirow[b]{3}{*}{ Model } & \multicolumn{3}{|c|}{ Unstandardized Standardized } & \multirow[b]{3}{*}{ Sig. } \\
\hline & \multicolumn{2}{|c|}{ Coefficients } & Coefficients & \\
\hline & B & Error & Beta & \\
\hline 1 (Constant) & 18.4 & 6.563 & & 2.810 .007 \\
\hline komunikasi & .289 & .110 & .316 & 2.625 .011 \\
\hline $\begin{array}{l}\text { lingkungan } \\
\text { kerja }\end{array}$ & .162 & .077 & .255 & 2.117 .038 \\
\hline
\end{tabular}

dan signifikan dari variabel bebas terhadap variabel terikat.

ANOVA $^{b}$

\begin{tabular}{|c|c|c|c|c|c|c|}
\hline \multirow{2}{*}{\multicolumn{2}{|c|}{ Model }} & \multicolumn{2}{|c|}{ Sum of } & \multirow{2}{*}{$\begin{array}{l}\text { Mean } \\
\text { Square }\end{array}$} & \multirow[b]{2}{*}{$\mathrm{F}$} & \multirow[b]{2}{*}{ Sig. } \\
\hline & & Squares & Df & & & \\
\hline \multirow[t]{3}{*}{1} & Regression & 123.823 & 2 & 61.912 & 9.669 & $.000^{\mathrm{a}}$ \\
\hline & Residual & 409.789 & 64 & 6.403 & & \\
\hline & Total & 533.612 & 66 & & & \\
\hline \multicolumn{7}{|c|}{ a. Predictors: (Constant), lingkungan kerja, komunikasi } \\
\hline \multicolumn{7}{|c|}{ b. Dependent Variable: kinerja karyawan } \\
\hline
\end{tabular}

Sumber : data diolah SPSS 16.0

Untuk kriteria uji $\mathrm{t}$ dilakukan pada tingkat $\alpha=5 \%$ dengan dua arah $(0,05)$ nilai tabel untuk $\mathrm{n}=67$ yaitu dan $\mathrm{dk}=\mathrm{n}-\mathrm{k}$ $67-2=65$.

1) Variabel komunikasi

Ada pengaruh signifikan antara komunikasi terhadap kinerja karyawan pada Pt.Jasa Marga (Persero) Tbk Cabang Belmera Medan dengan diperoleh nilai $t_{\text {hitung }}>t_{\text {tabel }}(2.625>1.66792$ ). Dengan demikian hipotesis diterima.

2) Variabel lingkungan kerja Ada pengaruh signifikan antara lingkungan kerja terhadap kinerja karyawanpada Pt.Jasa Marga (Persero) Tbk Cabang Belmera Medan dengan diperoleh nilai $t_{\text {hitung }}<t_{\text {tabel }}(2.117>1.66792)$ Dengan demikian hipotesis diterima.

\section{Uji F (simultan)}

Uji F (uji serentak) dilakukan untuk melihat secara bersama - sama (serentak) pengaruhn secara positif

$$
\mathrm{F}_{\text {tabel }}=\mathrm{n}-\mathrm{k}-1=67-2-1=64
$$

Berdasarkan persamaan di atas diperoleh nilai $\quad F_{\text {hitung }}>F_{\text {tabel }}(9.669$ >3.14) dengan demikian hipotesis diterima. Sehingga dapat disimpulkan bahwa ada pengaruh signifikan antara komunikasi dan lingkungan kerja terhadap kinerja karyawan pada Pt.Jasa Marga (Persero) Tbk Cabang Belmera Medan.

\section{Koefisien determinasi}

Pengujian koefisien determinasi $\left(\mathrm{R}^{2}\right)$ digunakan untuk mengukur proporsi atau presentase kemampuan model dalam menerangkan variabel terikat. Koefisien determinasi berkisar antara nol sampai satu $\left(0 \leq \mathrm{R}^{2} \leq 1\right)$. Jika $\mathrm{R}^{2}$ semangkin besar (mendekati satu), maka dapat dikatakan bahwa pengaruh variabel bebas (X) adalah besar terhadap variabel terikat (Y). Hal ini berarti model yang digunakan semangkin kuat untuk menerangkan pengaruh variabel bebas terhadap variabel terikat dan demikian sebaliknya. 
Model Summary

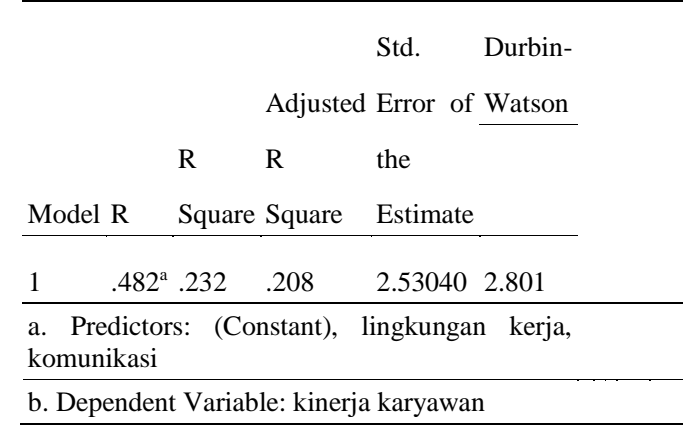

Sumber: data diolah SPSS 16.0

Koefisien determinasi diperoleh :

1) Nilai $R$ sebesar 0.482 sama dengan $48,2 \%$ yang menunjukkan bahwa hubungan antara variabel komunikasi dan lingkungan kerja dengan kinerja karyawan (Y) cukup erat.

2) Nilai R sguare (angka korelasi atau $r$ yang dikuadratkan) sebesar 0.232. $\mathrm{R}$ square disebut juga sebagai identifikasi determinasi. Besarnya nilai identifikasi 0.232 atau sama dengan $23,2 \%$. nilai tersebut berarti bahwa sebesar $23,2 \%$ kinerja karyawan dapat dijelaskan dengan menggunakan variabel komunikasi dan lingkungan kerja serta sisanya dipengaruhi oleh variabel lain yang tidak dimasukkan dalam penelitian ini.

\section{HASIL DAN PEMBAHASAN}

Berdasarkan hasil penelitian yang didasarkan pada hasil pengolahan data yang terkait dengan judul, kesesuaian teori, pendapat maupun penelitian terdahulu, maka dalam penelitian ini ada beberapa hal yang dapat dijelaskan, yaitu sebagai berikut:

\section{Pengaruh Komunikasi Terhadap Kinerja Karyawan Berdasarkan perhitungan} dengan SPSS diperoleh hasil korelasi antara komunikasi dengan kinerja karyawan diperoleh nilai korelasi hitung sebesar 0,289 dengan probabilitas sig 0,000, lebih kecil dari $\alpha=0,05$ atau $\mathrm{t}$ hitung. Dari hasil perhitungan diperoleh hasil bahwa signifikan $0,000>0,05, \quad$ ini menunjukkan adanya pengaruh yang signifikan antara variabel $\mathrm{X}_{1}$ dan $\mathrm{Y}$. maka hal ini menunjukkan semakin rendah komunikasi maka akan meningkatkan kinerja karyawanpada PT. Jasa Marga (persero) Tbk cabang belmera medan.

Hal ini didukung oleh penelitian terdahulu oleh Dewi (2007, hal. 3) menyatakan "bahwa komunikasi akan efektif apabila terjadi pemahaman yang sama dan pihak lain terangsang untuk berpikir atau melakukan sesuatu". Komunikasi dengan komunikasi yang efektif bukanlah hal yang sama. Kemampuan untuk berkomunikasi secara efektif akan menambah keberhasilan individu maupun organisasi, dan itu akan mempengaruhi kinerja karyawan

\section{Pengaruh Lingkungan Kerja Terhadap Kinerja Karyawan Berdasarkan perhitungan}

dengan SPSS diperoleh hasil korelasi antara lingkungan kerjadengan kinerja karyawan dari hasil perhitungan diperoleh bahwa signifikan $0,000<$ 0,05 , ini menunjukkan adanya pengaruh yang signifikan antara variabel $\mathrm{X}_{2}$ dan $\mathrm{Y}$. Dari tabel diatas, tentang pengaruh konflik kerja terhadap prestasi kerja diperoleh nilai 0,162 dengan probabilitas sig 0,000, lebih kecil dari $\alpha=0,05$ atau $t$ hitung. 
Hal ini juga menunjukkan tinggihnya komunikasi maka semakin meningkat juga kinerja karyawan PT. Jasa Marga (persero) Tbk cabang belmera medan

Menurut Nela dkk (2014) menunjukan bahwa ada lingkungan kerja pengaruh yang signifikan terhadap kinerja karyawan. Adapun paradigma dari penelitian ini pengaruh lingkungan kerja dengan kinerja karyawan

\section{Pengaruh Komunikasi dan Lingkungan Kerja Terhadap Kinerja Karyawan}

Berdasarkan hasil temuan penelitian ini mengenai pengaruh komunikasi dan lingkungan kerja terhadap kinerja karyawa pada PT. Jasa Marga (persero) Tbk cabang belmera medan yang menyatakan bahwa sudah jelas terbukti berpengaruh Hasil nilai R- Square yang diperoleh adalah 0,232atau $2,32 \%$ hal ini menunjukkan sekitar 2,32\% variabel kunerja karyawan (Y) dipengaruhi oleh komunikasi $\left(\mathrm{X}_{1}\right)$ dan lingkungan kerja $\left(\mathrm{X}_{2}\right)$. Dan sisanya dipengaruhi oleh variabel lainnya yang tidak diteliti.

Pada penelitian ini ketiga hipotesis ini diterima, yakni komunikasi $\left(\mathrm{X}_{1}\right)$ dan lingkungan kerja

\section{DAFTAR PUSTAKA}

SimanjuntakPayaman J.(2011). Manajemen dan Evaluasi Kinerja. Jakarta : Lembaga Penerbit Fakultas Ekonomi UI.

MiftahThoha. (2014). Perilaku Organisasi: Konsep Dasar dan Aplikasinnya.Jakarta : Rajawali Pers.

Anwar PrabuMangkunegara. (2014). Evaluasi Kinerja SDM.Bandung : PT. RefikaAditama.
$\left(\mathrm{X}_{2}\right)$ berpengaruh signifikan terhadap kinerja karyawan (Y) di PT. Jasa Marga (persero) Tbk Cabang belmera medan. Pengaruh yang signifikan mengandung makna bahwa hasil penelitian ini yang dikatakan positif dan berpengaruh sebesar 2,32\% merupakan gambaran umum dari seluruh PT. Jasa Marga (persero) Tbk cabang belmera medan.

Menurut Takasenseran dkk (2014) "Pengaruh Lingkungan Kerja, Komunikasi, dan Stres Kerja terhadap Kinerja karyawan" menunjukan bahwa ada lingkungan kerja, komunikasi, serta stres kerja secara simultan atau bersama-sama berpengaruh terhadap kinerja karyawan dan pengaruh nya adalah positif.

\section{PENUTUP}

Berdasarkan penelitian yang dilakukan maka dapat disimpulkan bahwa komunikasi dan lingkungan kerja berpengaruh secara signifikan terhadap kinerja karyawan pada PT. Jasa Marga (persero) Tbk cabng belmera medan.

sWibowo.(2007). Manajemen Kinerja.Jakarta : PT. Raja Grafindo Persada.

Papundu Tika. (2010). Budaya Organisasi dan Peningkatan Kinerja Perusahaan.Jakarta : PT. Bumi Aksara.

Anwar PrabuMangkunegara. (2013). Manajemen Sumber Daya Manusia Perusahaan. Bandung :PT. Remaja Rosdakarya. 
Juliandi, Azuar\&Irfan. (2013). Metodologi Penelitian Kuantitatif Edisi Pertama, Cita Pustaka Media Printis.

Husaini Usman.(2011). Manajemen. Jakarta : PT. Bumi Aksara.

Kadarman „JusufUdaya. (2001). Pengantar Ilmu

Manajemen.Jakarta : PT. Prenhalindo.

EdySutrisno. (2011). Budaya Organisasi.Jakarta : Kencana.

Aldo HerlambangGardjito, Mochammad Al Musadieq, Gunawan Eko Nurtjahjono. (2014). Pengaruh Motivasi Kerja dan Lingkungan Kerja Terhadap Kinerja Karyawan. Fakultas Ilmu Administrasi Universitas Brawijaya Malang. Jurnal Administrasi Bisnis (JAB) Vol. 13 No. 1 Agustus 2014.

Moeherino. (2012). Pengukuran Kinerja Berbasis Kompetensi.(2012). Jakarta : Rajawali Pers.

Ernie Tisnawati, KurniawanSaefullah. (2005). Pengantar Manajemen.
Jakarta : PT. Fajar Interpratama Mandiri.

Tri Budi Marwanto dan RiyadiNugroho. (2014). Pengaruh Kompensasi dan Lingkungan Kerja Tehadap Motivasi dan Desiplin Kerja Prajurit Di Satuan Kerja KRI X Armada RI KawasanTimur. Jurnal Ilmu Ekonomi \& Manajemen April 2014, Vol, 1.

Lucky Wulan Analisa. (2011). Pengaruh Motivasi Kerja dan Lingkungan Kerja Terhadap Kinerja Karyawan. Universitas Diponegoro Semarang.

Sugiyono. (2012). Metode Penelitian Bisni p, Pendekatan Kuantitatif, Kualitatif, dan R\&D. Bandung, Alfabeta CV

Dwi Agung NugrohoArianto. (2013). Pengaruh Kedisiplinan, Lingkungan Kerja dan Budaya Kerja Terhadap Kinerja Tenaga Pengajar. Jurnal Economia, Vol. 9, No. 2, Oktober 2013, Universits Islam Nahdlatul Ulama Jepara, Indonesia 